\title{
Polar bear Ursus maritimus conservation in Canada: an ecological basis for identifying designatable units
}

\author{
Gregory W. Thiemann, Andrew E. Derocher and Ian STIRLing
}

\begin{abstract}
Polar bears Ursus maritimus have a circumpolar distribution that is directly tied to the Arctic sea ice. Although they are wide-ranging, polar bears do not belong to a single population but rather are comprised of 19 largely discrete subpopulations, 13 of which are fully or partly under Canadian jurisdiction. These subpopulations are used to manage the sustainable harvest of polar bears in Canada but for conservation purposes the species is currently considered a single biological unit. Long-term climate warming has reduced the availability of sea ice that polar bears require for feeding, movement and reproduction, and continued declines in ice extent and duration are forecast to have significant negative effects on polar bears in some areas. Under the Canadian Species at Risk Act separate legal protection may be given to intraspecific groups (so called designatable units, DUs) that are genetically, geographically and/or biogeographically distinct. We examined the conservation status of polar bears across their Canadian range and compared large-scale ecosystem properties across subpopulations. We found that threats to the conservation of polar bears are not spatially uniform and we identified five DUs that captured broad patterns of polar bear biodiversity. We conclude that the use of DUs provides a biologically-sound framework for the conservation of polar bears.
\end{abstract}

Keywords Arctic, climate change, COSEWIC, management, polar bear, sea ice, Species At Risk Act, Ursus maritimus.

\section{Introduction}

P olar bears Ursus maritimus are distributed throughout the ice-covered marine areas of the circumpolar Arctic, especially over the shallower and more biologically productive continental shelves and inter-island channels. Nineteen subpopulations are currently recognized across the Arctic region and each is managed independently (Aars et al., 2006).

Gregory W. Thiemann (Corresponding author), Andrew E. Derocher and IAN Stirling* Department of Biological Sciences, CW405 Biological Sciences Building, University of Alberta, Edmonton, AB T6G 2E9, Canada. E-mail thiemann@ualberta.ca

*Also at: Canadian Wildlife Service, 5320122 Street, Edmonton, AB T6H 3S5, Canada.

Received 16 October 2007. Revision requested 11 January 2008.

Accepted 16 February 2008.
The polar bear is the most iconic symbol of the Arctic and thus any perception of a threat has generally been followed by significant national and international response. For example, in 1973, following years of concern that polar bears were being overexploited, Canada, USA, USSR, Norway and Denmark (for Greenland) signed the Agreement on the Conservation of Polar Bears (Prestrud \& Stirling, 1994; Aars et al., 2006). Among other things, the Agreement stipulates that each of the five signatory nations 'shall take appropriate action to protect the ecosystems of which polar bears are a part'.

In Canada threatened species are identified by the Committee on the Status of Endangered Wildlife in Canada (COSEWIC) and species are reassessed at least every 10 years. To date, polar bears have been considered a single biological unit with a shared conservation status (Stirling \& Taylor, 1999; COSEWIC, 2002). However, they occupy habitat that extends $>5,000 \mathrm{~km}$ from east to west and $3,000 \mathrm{~km}$ north to south (Fig. 1a) and it is now clear that the rate and consequences of climate-related sea ice declines vary in different parts of the Canadian Arctic (Stirling et al., 1999; Derocher et al., 2004; Stirling \& Parkinson, 2006; Amstrup et al., 2007). Consequently, it may now be more appropriate to consider the status of polar bear populations in different regions independently.

In 2002 the Government of Canada passed the Species at Risk Act, the wording of which allows 'distinct populations of wildlife' within a species to be afforded legal protection. Green (2005) described a systematic procedure to identify intraspecific units of conservation (designatable units, DUs) based on the hierarchical consideration of taxonomy, genetic distinction, range disjunction and biogeographical distribution. This approach was adopted by COSEWIC (2005) and intraspecific units can be given separate legal listings to protect diversity within a species. The DU approach has been applied to a variety of species including the Boreal felt lichen Erioderma pedicellatum, Blanding's turtle Emydoidea blandingii, coho salmon Oncorhynchus kisutch and woodland caribou Rangifer tarandus caribou (COSEWIC, 2005). Here we apply the DU framework to polar bears to examine the possibility that large-scale ecological processes have yielded groups of polar bears with regionally-specific conservation needs.

To examine the ecological factors relevant to polar bear conservation we incorporated four types of intrinsic data (genetic, spatial, demographic and life history), and two 

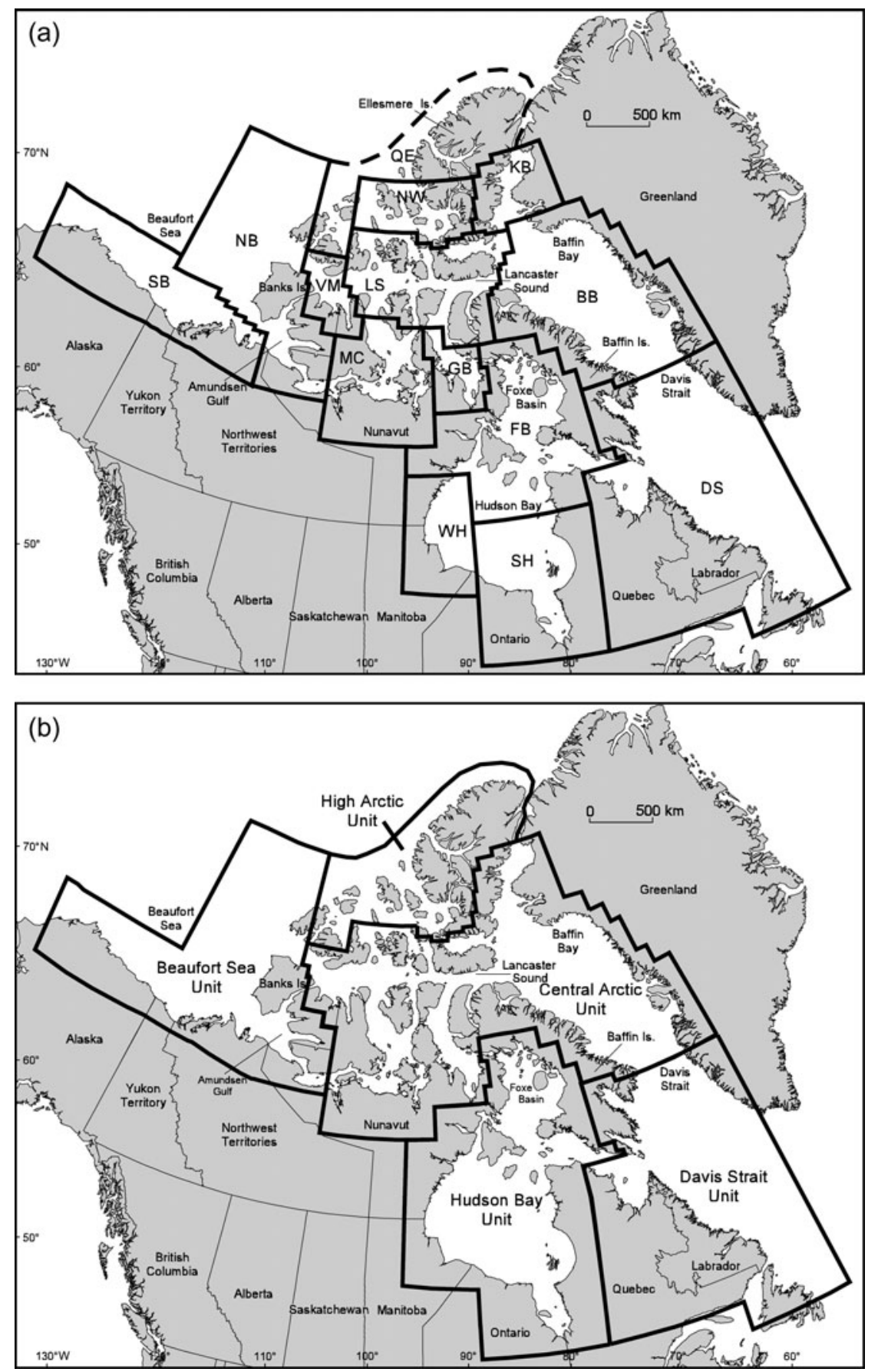

FIG. 1 (a) Current Canadian polar bear management zones as defined by the IUCN/SSC Polar Bear Specialist Group (Aars et al., 2006). NB, Northern Beaufort Sea; SB, Southern Beaufort Sea; VM, Viscount Melville; LS, Lancaster Sound; MC, M'Clintock Channel; GB, Gulf of Boothia; NW, Norwegian Bay; KB, Kane Basin; BB, Baffin Bay; FB, Foxe Basin; WH, Western Hudson Bay; SH, Southern Hudson Bay; DS, Davis Strait. The Queen Elizabeth (QE) population was previously used as a geographic catch-all to account for the northern tip of Ellesmere Island (IUCN/SSC Polar Bear Specialist Group, 2002) and is no longer recognized as a distinct subpopulation.

(b) Proposed designatable units (DUs) for polar bear conservation based on genetic, ecological and life history data (see text for details).

categories of extrinsic data (abiotic, including barriers established by land, multi-year ice and open water, and biotic, including the distribution and abundance of prey and overall biological productivity). We examined possible correlations between these physical and ecological properties and the conservation status of polar bears.

\section{Background}

Sea ice is the polar bear's primary habitat. It provides a platform upon which polar bears move, hunt, mate and sometimes den. In portions of their range where the sea ice melts completely, polar bears are forced to fast on land 
without access to the ringed seals Phoca hispida and bearded seals Erignathus barbatus that comprise most of their diet (Stirling et al., 1977; Iverson et al., 2006). In some areas long-term climate warming has caused ice breakup to occur earlier and periods of open water to be extended (Stirling et al., 1999; Stirling \& Parkinson, 2006; Regehr et al., $2007 \mathrm{~b}$ ). Consequently, bears have less time to accumulate body fat and may be forced to fast for longer periods. In areas where polar bears remain on the ice year-round, increased melting has resulted in decreased time on the biologically productive continental shelf (Regehr et al., 2007a). Climate-related habitat loss has resulted in declines in body condition, survival, reproduction and total abundance in some populations (Stirling et al., 1999; Hunter et al., 2007; Regehr et al., 2007a,b).

The polar bear is categorized as Vulnerable on the IUCN Red List because of projected declines in polar bear abundance and habitat quality (Aars et al., 2006; IUCN, 2007). Largely in response to evidence that climate warming has already affected the abundance and reproductive success of polar bears, the US Department of the Interior has listed the polar bear as threatened throughout its range under the Endangered Species Act (USFWS, 2008). This listing considers polar bears as a single population with a uniform conservation status. However, research used to inform the listing decision concluded that the long-term status of polar bears will probably vary across different polar ice ecoregions (Amstrup et al., 2007). Nevertheless, the utility of distinct population segments or DUs for the legal protection of polar bears remains unexplored.

In Canada hunting of polar bears is important to both the culture and economy of indigenous peoples, primarily Inuit (Freeman \& Wenzel, 2006). Although the overall management goal is to maximize the kill within sustainable limits, the success of this approach is contingent upon good scientific data and a relatively stable, predictable environment. Thus, the extensive loss of sea ice to date (Comiso, 2002; Stroeve et al., 2007), and forecast future loss (Meehl et al., 2007), presents a new and serious threat to the survival of polar bears. Although adverse effects of harvesting may, in principle, be mitigated by hunting restrictions, the interaction of climate change and harvest make it more difficult to ensure a sustainable harvest.

Section 2(1) of the Species at Risk Act allows a 'wildlife species' to be defined as any 'geographically or genetically distinct population'. Although the Act does not provide an explicit definition for a 'distinct population', COSEWIC has adopted a methodology for identifying DUs for protection under the Act (COSEWIC, 2005; Green, 2005). The first step in this method is to examine the species as a whole and determine whether a single designation would accurately reflect the conservation status of the entire species. If not, the second step is to identify potential DUs by sequentially examining: (1) named subspecies or varieties, (2) genetically distinct units, (3) geographically distinct units, and (4) biogeographically distinct units. In the third step DUs are reassessed to ensure they accurately reflect the conservation status of the individual groups.

\section{Designatable units for polar bears}

In different areas polar bears belong to ecosystems that differ fundamentally in their structure and functioning. In addition, the ecological effects of climate change vary substantially throughout the Canadian Arctic. Thus, although all polar bears in Canada belong to a single species they do not share a single, uniform conservation status. The identification and assessment of possible DUs is therefore warranted. For polar bears, no named subspecies or varieties have been recognized (Wilson, 1976).

\section{Genetically distinct units}

Current management subpopulations (Fig. 1a) reflect polar bears' fidelity to denning, summer refugia, and foraging areas (Jonkel, 1969; Schweinsburg \& Lee, 1982; Lentfer, 1983; Stirling et al., 1984; Derocher \& Stirling, 1990; Mauritzen et al., 2001; Taylor et al., 2001), and long-distance migration between populations is limited (Stirling et al., 1977; Lentfer, 1983; Taylor \& Lee, 1995). The conditions therefore exist for groups of polar bears to have developed distinct genetic adaptations to local environmental conditions.

Paetkau et al. (1999) examined 16 microsatellite loci in polar bears from 12 of the 13 Canadian subpopulations and identified four major genetic clusters (Fig. 2). Relative to the variability between all groups, they found a high degree of

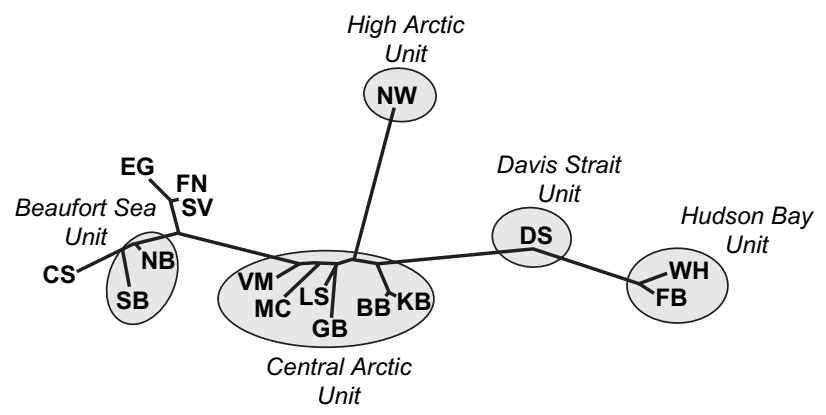

Fig. 2 Graphical representation of genetic distances between polar bear subpopulations (for abbreviations, see Fig. 1a; Paetkau et al., 1999), and the five designatable units (see text for details). Clustering is based on the genotype likelihood ratio distance and represents relative patterns of similarity among subpopulations. Overall, the genetic variability among polar bears is less than that observed in intraspecific groups of black bears Ursus americanus or brown bears Ursus arctos but patterns still reflect ecological relationships among subpopulations. The international Chukchi Sea (CS), East Greenland (EG), Franz Josef Land-Novaya Zemlya (FN), and Svalbard (SV) subpopulations are not discussed in this paper. Modified from Paetkau et al. (1999). 
similarity between the Northern and Southern Beaufort Sea subpopulations, and between the Western Hudson Bay and Foxe Basin subpopulations. Although genetic data from Southern Hudson Bay were unavailable, movement and foraging data (Stirling et al., 1999; Thiemann, 2006) suggest that Western and Southern Hudson Bay are similar. Bears from Baffin Bay and Kane Basin are genetically homogeneous and formed a larger cluster with Lancaster Sound, Gulf of Boothia, M'Clintock Channel and Viscount Melville Sound. Although Paetkau et al. (1999) grouped Davis Strait with Foxe Basin and Western Hudson Bay subpopulations, their data indicated that Davis Strait bears are genetically intermediate between Foxe Basin and the Central Arctic groups (Fig. 2). Bears from the Norwegian Bay subpopulation are genetically distinct. The genetic relationships between subpopulations were consistent with movement patterns, i.e. the occasional movement of individuals between subpopulations appeared to be responsible for genetic similarities.

Although Paetkau et al. (1999) concluded the observed genetic differences are relatively small compared to other bear species and do not indicate multiple evolutionary significant units, they noted that differences in important adaptive traits may exist between groups of polar bears. Because microsatellite sequences are neutral genetic markers they reflect the amount of time that groups have been separated, rather than the amount of evolutionary adaptation that has occurred. Other, phenotypic, differences may reflect recent, adaptive, genetic diversity.

These results (Paetkau et al., 1999) suggest that polar bears in Canada comprise five distinct genetic units that could be considered as DUs: Beaufort Sea, Central Arctic, High Arctic, Hudson Bay/Foxe Basin and Davis Strait (Fig 1b). Although microsatellite data indicate some genetic similarity between members of Hudson Bay/Foxe Basin and Davis Strait we consider these as separate DUs because of the distinct ecological conditions in the two regions (see below). To account for the northern tip of Ellesmere Island we have combined the previously recognized Queen Elizabeth subpopulation (IUCN/SSC Polar Bear Specialist Group, 2002) with the Norwegian Bay population to form the High Arctic DU.

\section{Biogeographically distinct units}

Here, we incorporate larger-scale ecogeographical data and examine whether significant genetic differences are correlated with biologically significant phenotypic differences. The areas covered by the five possible DUs include substantial ecological and geographical variability (Table 1).

Geography The polar bears of the Hudson Bay DU (Western Hudson Bay, Southern Hudson Bay and Foxe Basin) comprise a distinct genetic, ecological and geographical group. Although bears in these three subpopulations are separated during the ice-free season, their foraging and breeding ranges may overlap substantially (Paetkau et al., 1999; Stirling et al., 1999; A.E. Derocher, unpubl. data). A small number of polar bears move through Hudson Strait (Stirling \& Kiliaan, 1980; Taylor et al., 2001), resulting in some genetic similarity between the Hudson Bay and Davis Strait DUs (Paetkau et al., 1999). However, the large land masses of eastern mainland Canada and Baffin Island limit movement between Hudson Bay and the Atlantic Ocean. Similarly, Fury and Hecla Strait forms a narrow oceanographic connection between Foxe Basin and Gulf of Boothia, with little genetic exchange (Paetkau et al., 1999).

Banks and Victoria Islands serve as land barriers between the Beaufort Sea DU and the polar bears of the Central Arctic. The rugged topography and ice-fields of Ellesmere and Devon Islands, and thick multi-year sea ice between the archipelago islands where seal densities are lower (Kingsley et al., 1985), effectively separate the High Arctic and Central Arctic DUs. Within the Central Arctic DU the islands of the archipelago separate six subpopulations (Bethke et al., 1996; Taylor et al., 2001). However, these separations appear to be relatively weak, and genetic (Paetkau et al., 1999), ecological (Thiemann et al., in press), and conservation similarities (Stirling \& Parkinson, 2006) between these subpopulations support their consideration as a single DU.

Ice conditions The abundance and availability of sea ice habitat is the most important environmental factor affecting the distribution and movement of polar bears (Schweinsburg \& Lee, 1982; Schweinsburg et al., 1982; Stirling et al., 1993, 1999, 2004; Ferguson et al., 1998, 2001; Mauritzen et al., 2001; Parks et al., 2006). In addition to serving as a substrate for polar bears to travel, hunt, mate and den, ringed and bearded seals depend on the sea ice for reproduction and as a place to rest and moult. Consequently, the local abundance of polar bears is directly related to the availability of suitable sea ice habitat.

Optimal polar bear habitat is generally a mix of stable land-fast ice and dynamic offshore pack ice (Stirling et al., 1993). Seal abundance is reduced in areas of multi-year ice (Kingsley et al., 1985) and because polar bears avoid areas where hunting is poor, multi-year ice can form a significant barrier to movement (Paetkau et al., 1999; Taylor et al., 2001). The fast ice that forms over the biologically productive continental shelf is prime ringed seal habitat. This annual ice is thin enough for ringed seals to maintain breathing holes yet stable enough for the construction of birth and haul-out lairs (McLaren, 1958; Smith \& Stirling, 1975; Hammill \& Smith, 1989). Polar bears, particularly adult females with cubs (Stirling et al., 1993), detect these lairs by smell and dig into them to capture the seals within. Other age and sex classes of polar bears often forage farther offshore near the floe edge (Stirling et al., 1993). 
TABLE 1 Selected environmental, ecological and demographic characteristics of proposed designatable units (DUs; Fig. 1b) and subpopulations (Fig. 1a) of polar bears in Canada.

\begin{tabular}{|c|c|c|c|c|c|c|c|c|c|}
\hline Proposed DU & $\begin{array}{l}\text { Subpopulation } \\
\text { (Fig. 1a) }\end{array}$ & $\begin{array}{l}\text { Population size } \\
(2 \mathrm{SE} \text { or } 95 \% \mathrm{CI})^{1}\end{array}$ & Denning habitat $^{2}$ & Sea ice regime & $\begin{array}{l}\text { Ice-free } \\
\text { in summer? }\end{array}$ & $\begin{array}{l}\text { Relative } \\
\text { productivity }^{3}\end{array}$ & $\begin{array}{l}\text { Prey } \\
\text { diversity }^{4}\end{array}$ & $\begin{array}{l}\text { Hunting } \\
\text { pressure } \\
\text { index }^{5}\end{array}$ & $\begin{array}{l}\text { Population } \\
\text { trend }^{1}\end{array}$ \\
\hline \multirow[t]{2}{*}{ Beaufort Sea } & N. Beaufort (NB) & $980(155)$ & $\begin{array}{l}\text { Multi-year } \\
\text { ice \& land }\end{array}$ & $\begin{array}{l}\text { Annual \& } \\
\text { multi-year }\end{array}$ & No & Low & Low & 0.55 & Stable \\
\hline & S. Beaufort (SB) & $1,526(315)$ & $\begin{array}{l}\text { Multi-year } \\
\text { ice \& land }\end{array}$ & $\begin{array}{l}\text { Annual \& } \\
\text { multi-year }\end{array}$ & No & Low & Low & 0.72 & $\begin{array}{l}\text { Declining } \\
\text { or stable? }\end{array}$ \\
\hline High Arctic & Norwegian Bay (NW) & $190(88)$ & Land & $\begin{array}{l}\text { Annual \& } \\
\text { multi-year }\end{array}$ & No & Low & Low & 0.75 & Declining \\
\hline \multirow[t]{6}{*}{ Central Arctic } & $\begin{array}{l}\text { Viscount Melville } \\
\text { (VM) }\end{array}$ & $161(40)$ & Land & $\begin{array}{l}\text { Annual \& } \\
\text { multi-year }\end{array}$ & No & Low & Low & 0.57 & Increasing \\
\hline & Lancaster Sound (LS) & $2,541(782)$ & Land & $\begin{array}{l}\text { Annual \& } \\
\text { multi-year }\end{array}$ & No & High & High & 0.87 & Stable \\
\hline & Baffin Bay (BB) & $2,074(530)$ & Land & Annual & Yes & High & High & 0.93 & Declining \\
\hline & Kane Basin (KB) & $164(70)$ & Land & $\begin{array}{l}\text { Annual \& } \\
\text { multi-year }\end{array}$ & No & Medium & Medium & 0.73 & Declining \\
\hline & M'Clintock Channel (MC) & $284(118)$ & Land & $\begin{array}{l}\text { Annual \& } \\
\text { multi-year }\end{array}$ & No & Low & Low & 1.00 & Increasing \\
\hline & Gulf of Boothia (GB) & $1,523(570)$ & Land & $\begin{array}{l}\text { Annual \& } \\
\text { multi-year }\end{array}$ & No & Low & Medium & 0.62 & Stable \\
\hline \multirow[t]{3}{*}{ Hudson Bay } & Foxe Basin (FB) & $2,197(520)$ & Land & $\begin{array}{l}\text { Annual, little } \\
\text { multi-year }\end{array}$ & Yes & Medium & High & 0.89 & Stable \\
\hline & W. Hudson Bay (WH) & $935(141)$ & Land & Annual & Yes & Medium & Medium & 0.70 & Declining \\
\hline & S. Hudson Bay (SH) & $681(280)$ & Land & Annual & Yes & Medium & Medium & 0.86 & Stable \\
\hline Davis Strait & Davis Strait (DS) & $1,650(650)$ & Land & Annual & Yes & High & High & 0.88 & Unknown \\
\hline
\end{tabular}

${ }^{1}$ From IUCN/SSC Polar Bear Specialist Group (2006), Regehr et al. (2006), Obbard et al. (2007), Stirling et al. (2007)

${ }^{2}$ From Stirling et al. (1980, 1984), Schweinsburg et al. (1984), Amstrup \& Gardner (1994), Messier et al. (1994), Van de Velde et al. (2003), Fischbach et al. (2007)

${ }^{3}$ From Subba Rao \& Platt (1984), Stirling \& Øritsland (1995)

${ }^{4}$ Low, 2-3 species; Medium, 4-5 species; High, 6-8 species

${ }^{5}$ Historical annual removals/potential maximum annual removals (provides a measure of relative harvest intensity); from IUCN/SSC Polar Bear Specialist Group (2006) 
Within the Central Arctic DU sea ice provides both a barrier and a connection between subpopulations. For instance, multi-year ice in eastern Viscount Melville Sound separates this subpopulation from the Lancaster Sound subpopulation. However, bears from both areas may use the multi-year ice as a summer refuge (Taylor et al., 2001), which contributes to their genetic similarity (Paetkau et al., 1999). Lancaster Sound and Baffin Bay polar bears are separated, mainly during the summer, by the North Water Polynya, a large area of annually-recurring open water (Stirling, 1997). Although polar bears would be unlikely to swim across such an expanse of water, the sea ice surrounding the North Water is probably dynamic enough to provide a connection between Lancaster Sound and Baffin Bay. Consistent with these oceanographic connections, polar bears within the Central Arctic DU display strong genetic (Paetkau et al., 1999) and foraging similarities (Thiemann et al., in press; see below).

The Baffin Bay and Davis Strait subpopulations are separated for management purposes by a line that extends from Cape Dyer on Baffin Island to Disko Island, Greenland. In winter and early spring this area is generally covered with consolidated pack ice that could easily be traversed by polar bears (Stirling et al., 1980). However, ocean currents and patterns of sea ice breakup and freezeup contribute to the separation of Baffin Bay and area of Davis Strait. Specifically, the West Greenland current flows northward along the western coast of Greenland before a portion of the current is shifted westward by the submarine Davis Strait Ridge (Dunbar, 1951). The result is a counterclockwise gyre in the area of the Davis Strait subpopulation (Stirling et al., 1980). Within the Baffin Bay region the West Greenland Current continues northward before joining the south-flowing Baffin Bay Current. This south-flowing cold water current, along with the deep fiords and bays of eastern Baffin Island, results in earlier freeze-up and later breakup in Baffin Bay than in Davis Strait. Therefore, despite ocean currents that flow across the subpopulation boundary, different ecological conditions in Baffin Bay and Davis Strait appear to discourage movement between these subpopulations (Stirling et al., 1980) and contribute to a degree of spatial separation that has resulted in significant genetic differences (Paetkau et al., 1999). Fisheries and Oceans Canada has also identified the areas of Baffin Bay and Davis Strait as distinct ecoregions, with the boundary occurring at Cape Dyer (Powles et al., 2004).

Consistent with previous analyses of Canada's ocean ecosystems (Powles et al., 2004; Spalding et al., 2007), we identified the polar bear subpopulations of Foxe Basin, Western Hudson Bay and Southern Hudson Bay as comprising a single DU. This area is heavily influenced by a large terrestrial freshwater input. A weak ocean current enters the area through Fury and Hecla Strait and another current leaves via Hudson Strait (Dunbar, 1951). The entire region becomes ice-free in summer and polar bears throughout the DU spend significant amounts of time on land without access to prey (Stirling et al., 1977; Stirling \& Parkinson, 2006). Although the ice-free season is shorter in Foxe Basin than in Hudson Bay, the overall sea ice regime and geographical isolation of the area appears to contribute to the genetic (Paetkau et al., 1999) and ecological similarities (Thiemann, 2006) among bears within the Hudson Bay DU.

Productivity and prey diversity Sea ice plays a significant role in determining productivity and ecosystem structure, which show distinct variation among the proposed DUs. In the Beaufort Sea primary productivity is generally lower than in the eastern Canadian Arctic. Primary production in the nearshore Beaufort Sea is $10-15 \mathrm{~g} \mathrm{~m}^{-2} \mathrm{yr}^{-1}$ (Alexander, 1974) compared with $60 \mathrm{~g} \mathrm{~m}^{-2} \mathrm{yr}^{-1}$ in Lancaster Sound (Welch et al., 1992) and 40-75 $\mathrm{g} \mathrm{m}^{-2} \mathrm{yr}^{-1}$ in Baffin Bay (Grainger, 1975). The relatively low productivity of the Beaufort Sea results in lower ringed seal densities (Stirling \& Øritsland, 1995) and a marine mammal community limited to ringed seals, bearded seals, and beluga Delphinapterus leucas and bowhead whales Balaena mysticetus.

Productivity in polynyas may be several times higher than in adjacent ice-covered water and these annuallyrecurring areas of open water provide important habitat for Arctic sea birds and marine mammals (Stirling, 1980). One of the most biologically productive areas of the Beaufort Sea is the Cape Bathurst Polynya, in Amundsen Gulf between Banks Island and the mainland coast (Fig. 1; Stirling, 1997). This area is important foraging habitat for bears of both Beaufort Sea subpopulations (Stirling, 2002) and the shared use of this important biological feature supports the consideration of a single Beaufort Sea DU.

In the High Arctic DU primary productivity may be reduced because less light penetrates the abundant multiyear ice than through annual ice. However, there is considerable annual ice in the south of this area and primary productivity may be underestimated (Pomeroy, 1997).

The relatively high biological productivity of the Lancaster Sound region (Welch et al., 1992) supports a rich diversity of marine mammals that may be preyed upon by bears in adjacent subpopulations. Ringed seals, bearded seals, and beluga whales are abundant and polar bears may also hunt narwhals Monodon monoceros, walrus Odobenus rosmarus and harp seals Pagophilus groenlandicus in some areas of the Arctic archipelago (Thiemann, 2006). Bears in Lancaster Sound, Kane Basin, and Baffin Bay share access to a variety of marine mammal prey that occur in and around the North Water Polynya, and smaller recurring polynyas and shoreleads occur throughout the archipelago (Stirling, 1997). The combination of shallow, productive seas and a mix of annual and multi-year ice and open water create ecological conditions that are similar across the Central Arctic DU. 
The relatively warm waters of the North Atlantic in the Davis Strait region provide high biological productivity and a diversity of marine mammal prey. There are major whelping patches of both harp seal and hooded seal Cystophora cristata in this area and both species are predated by polar bears in Davis Strait (Iverson et al., 2006; Thiemann et al., in press). The unique prey assemblage and oceanographic characteristics of the Davis Strait region support its consideration as a separate DU.

The overall productivity of Hudson Bay is generally intermediate between the Arctic Basin and the North Atlantic (Stirling et al., 1977). In addition to ringed seals and bearded seals, polar bears in the Hudson Bay DU have access to beluga whales and localized or seasonal access to harp seals, harbour seals Phoca vitulina, walrus and narwhals (Thiemann, 2006).

Morphology, ecology and life history Inherited characters such as morphology, life history and behaviour provide evidence of genetic distinctiveness between groups (COSEWIC, 2005). Because they are affected by factors such as food supply and habitat quality, such phenotypic traits also reflect localized ecological differences. Thiemann et al. (in press) examined the fatty acid signatures of polar bears across their Canadian range to generate quantitative estimates of diet composition (Iverson et al., 2004, 2006). The overall diet patterns mirrored the genetic relationships identified by Paetkau et al. (1999; Figs 3 \& 4). Specifically, polar bears appear to forage beyond their own subpopulation boundaries but prey resources and polar bear diets are similar within the proposed DUs.

Consistent with the relatively low ecosystem productivity, polar bears in the Beaufort Sea DU are generally smaller (Derocher \& Stirling, 1998) and the age of females at first reproduction is later (Stirling, 2002) than bears in the eastern Canadian Arctic. Females in the Beaufort Sea do not begin breeding until 5 years of age, 1 year later than in Western Hudson Bay, Davis Strait or Lancaster Sound (Stirling et al., 1976, 1980, 1984; Ramsay \& Stirling, 1988; Derocher \& Stirling, 1998). Multi-year ice is available to bears in the Beaufort Sea year-round as the floe edge recedes to the north in summer but does not melt away completely. Therefore, unlike most other areas, females in the Beaufort Sea DU can excavate maternity dens on the sea ice (Lentfer, 1975; Amstrup \& Gardner, 1994). However, when the sea ice retreats past the edge of the continental shelf it lies over deep water that is relatively unproductive (Regehr et al., 2007a).

Data on the ecology and life history of polar bears in the High Arctic DU are limited. Considering the preponderance of multi-year ice and the low densities of ringed seals (Kingsley et al., 1985), bears in this DU are probably small and slow-growing. The limited data suggest that reproductive rates are low even among prime-age females ( $>6$ years old; IUCN/SSC Polar Bear Specialist Group, 2006).

Within the Central Arctic DU ecological and reproductive productivity are locally variable. Low ecosystem productivity contributes to the small size (Derocher \& Stirling, 1998) and slow reproduction (IUCN/SSC Polar Bear Specialist Group, 2006; Taylor et al., 2006) of bears in the Gulf of Boothia and M'Clintock Channel relative to other areas. In contrast, primary productivity may be high in the Lancaster Sound portion of the Central Arctic DU and polar bears may grow larger there (Derocher \& Stirling, 1998) and have higher litter production rates (IUCN/SSC Polar Bear Specialist Group, 2006). Although growth rates and productivity may show localized differences within the Central Arctic DU, there are general similarities in denning

\section{Squared Euclidean Distance}

\begin{tabular}{cccccc}
0 & 5 & 10 & 15 & 20 & 25 \\
\hline & 1 & 1 & 1 & \\
\hline
\end{tabular}

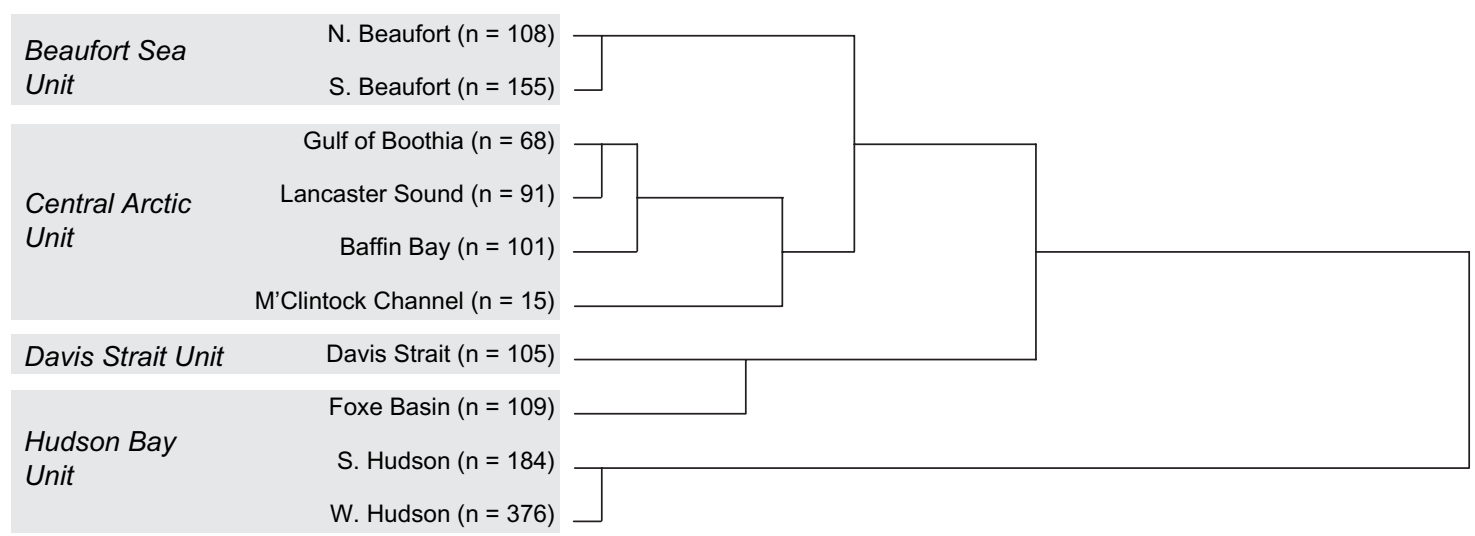

Fig. 3 Hierarchical cluster analysis of average fatty acid signatures of polar bears ( $\geq 2.5$ years old) in 10 Canadian subpopulations, with designatable units (see text for details) indicated. Clusters were formed based on squared Euclidean distance, using 64 fatty acids and the between-groups linkage method. Modified from Thiemann et al. (in press). 


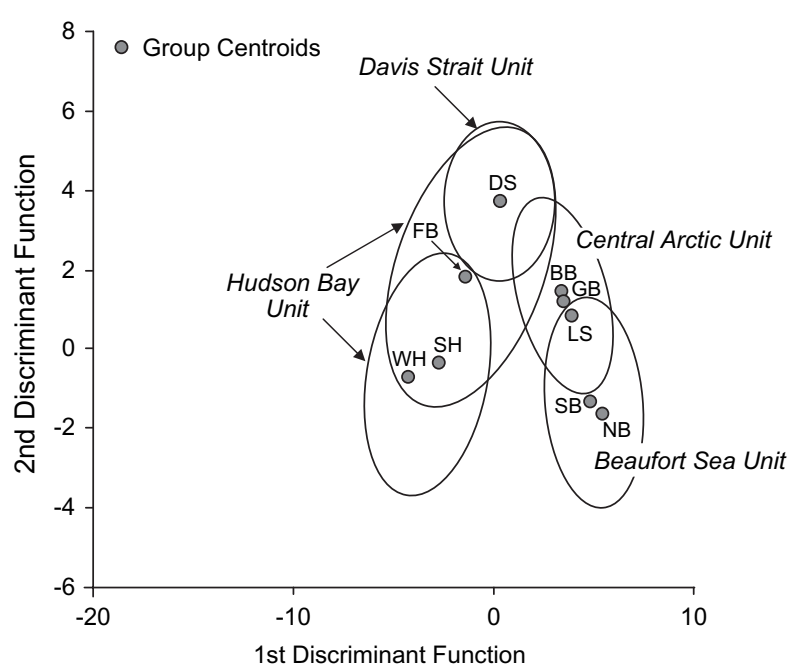

FIG. 4 Discriminant analysis of polar bears ( $\geq 2.5$ years old) in nine Canadian subpopulations (for abbreviations see Fig. 1a), with designatable units (see text for details) indicated, using 17 fatty acids and the same samples as Fig. 3. The first and second discriminant functions accounted for $88 \%$ of total variance. Discriminant analysis classified $80.9 \%$ of original cases and $79.8 \%$ of cross-validated cases to their correct region. Ellipses represent $95 \%$ data point clouds. Modified from Thiemann et al. (in press).

habitat, sea ice regime, and foraging patterns (Figs $3 \& 4$ ) across this region.

Reproductive rates in the Davis Strait DU tend to be higher than in most other areas of the Canadian Arctic (Stirling et al., 1980), probably because of the region's relatively warm waters, high productivity, and diverse and abundant prey fauna. In addition to ringed, bearded, and harbour seals, approximately 6 million harp seals inhabit the waters of the North-west Atlantic (DFO, 2005). Each spring, harp seals congregate in vast numbers along the coasts of Newfoundland and Labrador to pup and moult, and dietary analyses indicate that polar bears from the Davis Strait DU make extensive use of this resource (Iverson et al., 2006; Thiemann et al., in press). Satellite telemetry indicates that polar bears from south-eastern Baffin Island migrate southward to the whelping patch in spring before returning to the Island for the ice-free season (I. Stirling, unpubl. data). Predictable access to huge numbers of harp seals is a defining characteristic of the Davis Strait DU.

The life history pattern of polar bears in Hudson Bay is defined by a prolonged onshore period that begins when the sea ice of Hudson Bay melts completely in June or July (Jonkel, 1969; Stirling et al., 1977). While on land the bears fast and rely on stored fat reserves until freeze-up c. 4 months later. Pregnant females remain on shore for 8 months or more during which time they den and give birth to their young (Ramsay \& Stirling, 1988). The counterclockwise currents of Hudson Bay cause the ice to breakup earliest in the western portion of the Bay, with bears coming ashore earliest in north-eastern Manitoba. Breakup occurs later along the coasts of Ontario and Quebec and the bears of Foxe Basin move ashore latest as the sea ice may persist in this area until late August. Despite localized differences in the timing of sea ice formation and breakup, polar bears throughout the Hudson Bay DU are likely to be affected by long-term climate warming (Stirling et al., 1999; Derocher et al., 2004; Stirling \& Parkinson, 2006; Obbard et al., 2006, 2007; Regehr et al., 2007b). Spatial variability in sea ice breakup may also diminish established population boundaries as bears remain on the ice longer and potentially show reduced fidelity to onshore sites (Derocher et al., 2004).

\section{Polar bear conservation in Canada}

If a species as a whole shares a single conservation status then DUs are unnecessary (Green, 2005). However, there is considerable variation in important aspects of the biology and habitat of polar bears in Canada and we therefore conclude that a DU approach to their conservation is warranted. The significance of this ecological variability has increased with the onset of rapid climate warming and degradation of the sea ice habitat. The five DUs proposed here are not intended to serve as management units, and the sustainable harvest of polar bears should continue to be managed at the level of independent subpopulations. Rather, the DUs we have proposed represent units that are genetically, geographically, and ecologically separable. Next, we examine how these groups differ in the threats they face and/or their risk of extinction.

Polar bears in the southernmost portion of their range have been those most affected by climate warming (Stirling et al., 1999, 2004; Derocher et al., 2004; Stirling \& Parkinson, 2006; Regehr et al., 2007b). Because of progressively earlier sea ice breakup in Western Hudson Bay, Southern Hudson Bay and Foxe Basin (Stirling \& Parkinson, 2006), bears in the Hudson Bay DU have less time to hunt seals in spring and summer when ringed seals are most available and polar bear food intake is at its peak. Consequently, the bears are forced to fast onshore for longer periods with less stored fat on their bodies (Stirling et al., 1999; Obbard et al., 2006). Because parturient females rely on stored fat reserves for gestation and the first 3 months of lactation, this decline in condition has resulted in declining reproductive performance and population size in Western Hudson Bay (Derocher \& Stirling, 1992, 1995; Stirling et al., 1999; Regehr et al., 2007b). Although the harvest quota for this population was recently reduced in response to the population decline, the impacts of climate-related habitat loss will make sustainable management of Canada's polar bear populations increasingly difficult. 
Climate change is also affecting the other DU regions, albeit at different rates and in different ways. In the Beaufort Sea, Fischbach et al. (2007) found that the proportion of females denning on the pack ice is declining as more bears den on land in Alaska, apparently in response to larger areas of open water. Amstrup et al. (2006) documented three separate cases of polar bears hunting and cannibalizing other polar bears in 2004, and Stirling et al. (2008) discovered 14 sites where polar bears had clawed through solid ice in attempts to capture ringed seals below sheets of rafted ice. In both reports, the authors suspected that reductions in suitable sea ice habitat had played a role. Recent studies have found that population growth in Southern Beaufort Sea becomes negative when the ice-free period exceeds c. 125 days (Hunter et al., 2007; Regehr et al., 2007a). Polar bear populations will probably decline rapidly if recent patterns of ice distribution and open water persist (Hunter et al., 2007; Regehr et al., 2007a).

Analysis of new Davis Strait DU inventory data is currently underway but existing information is scarce (IUCN/SSC Polar Bear Specialist Group, 2006). However, this area has undergone substantial warming and sea ice decline over the last 2 decades (Comiso \& Parkinson, 2004; Moore, 2006). The extent of sea ice may affect the survival and abundance of harp seal pups (Johnston et al., 2005) and thus affect polar bear food supply (Derocher et al., 2002; Iverson et al., 2006). In the Central Arctic DU multi-year ice provides a more predictable environment for polar bears relative to southern populations, where the annual ice-free season largely defines life history patterns. However, it seems likely that continued climate warming will negatively affect bears in the Central Arctic DU. Because of its extreme latitude, the High Arctic DU may be protected from the effects of climate change in the short-term. However, its small population size (200-300 individuals) makes it vulnerable to Allee effects (Molnár et al., 2008) and genetic drift. If this DU were found to have $<250$ mature individuals it may be afforded Endangered status under COSEWIC's (2006) assessment process. However, such a designation would require a full population assessment. Considering the ecological and genetic isolation of this group of polar bears, such a study would be extremely valuable.

Derocher et al. (2004) predicted that polar bear subpopulation boundaries would weaken due to changes in sea ice distribution and habitat connectivity. In 2007, of nine female polar bears fitted with satellite collars in Western Hudson Bay, six came ashore in Southern Hudson Bay (A.E. Derocher, unpubl. data). The boundaries between management subpopulations have always been somewhat artificial because the distribution of polar bears is defined more by a continuum of home ranges than by absolute barriers to movement (Taylor \& Lee, 1995; Amstrup et al., 2005). It therefore seems unreasonable to expect these divisions to hold up in the face of rapid ecological change in Arctic marine ecosystems. A broad approach that accounts for large-scale ecological forces may provide a better framework for studying polar bear biology.

The five biological units we have identified differ in their conservation status and therefore warrant consideration as separate DUs under the Canadian Species at Risk Act. These DUs reflect biologically significant genetic, phenotypic, and biogeographical differences in polar bears across their Canadian range. Considering the vast geographical distribution of the species and the spatially variable ecological impacts of climate change, the continued consideration of polar bears as a single biological unit is untenable. Such an approach necessitates a single conservation strategy that within some regions may either be too conservative or too permissive. The DUs we have proposed are consistent with COSEWIC's assessment guidelines and would allow this iconic species to be more prudently conserved in the face of a rapidly deteriorating Arctic environment. We urge COSEWIC to assess the status of polar bears using the more biologically-sound approach of separate units of biodiversity.

\section{Acknowledgements}

This work was supported by the Canadian Wildlife Federation, Natural Sciences and Engineering Research Council of Canada, Alberta Ingenuity Fund, the Killam Trusts, the University of Alberta, the Canadian Wildlife Service, and WWF (Canada). M. Festa-Bianchet and an anonymous reviewer provided helpful comments on an earlier version of the manuscript.

\section{References}

Aars, J., Lunn, N.J. \& Derocher, A.E. (2006) Polar Bears: Proceedings of the 14th Working Meeting of the IUCN/SSC Polar Bear Specialist Group. IUCN, Gland, Switzerland.

Alexander, V. (1974) Primary productivity regimes of the nearshore Beaufort Sea, with reference to potential roles of ice biota. In The Coast and Shelf of the Beaufort Sea; Proceedings of a Symposium on Beaufort Sea Coast and Shelf Research (eds J.C. Reed \& J.E. Sater), pp. 609-632. Arctic Institute of North America, Arlington, USA.

Amstrup, S.C., Durner, G.M., Stirling, I. \& McDonald, T.L. (2005) Allocating harvests among polar bear stocks in the Beaufort Sea. Arctic, 58, 247-259.

Amstrup, S.C. \& GARDNer, C. (1994) Polar bear maternity denning in the Beaufort Sea. Journal of Wildlife Management, 58, 1-10.

Amstrup, S.C., Marcot, B.G. \& Douglas, D.C. (2007) Forecasting the Range-wide Status of Polar Bears at Selected Times in the 21st Century. US Geological Survey Administrative Report, Reston, USA [http://www.usgs.gov/newsroom/special/polar_bears/docs/ USGS_PolarBear_Amstrup_Forecast_lowres.pdf, accessed 25 January 2008].

Amstrup, S.C., Stirling, I., Smith, T.S., Perham, C. \& Thiemann, G.W. (2006) Recent observations of intraspecific 
predation and cannibalism among polar bears in the southern Beaufort Sea. Polar Biology, 29, 997-1002.

Bethie, R., Taylor, M., Amstrup, S.C. \& Messier, F. (1996) Population delineation of polar bears using satellite collar data. Ecological Applications, 6, 311-317.

Comiso, J.C. (2002) A rapidly declining perennial sea ice cover in the Arctic. Geophysical Research Letters, 29, 1956.

Comiso, J.C. \& Parkinson, C.L. (2004) Satellite-observed changes in the Arctic. Physics Today, 57, 38-44.

COSEWIC (Committee on the Status of Endangered Wildlife in CANADA) (2002) COSEWIC Assessment and Update Status Report on the Polar Bear Ursus maritimus in Canada. COSEWIC, Ottawa, Canada.

COSEWIC (Committee on the Status of Endangered Wildlife in CANADA) (2005) Guidelines for Recognizing Designatable Units Below the Species Level. COSEWIC, Ottawa, Canada [http:// www.cosewic.gc.ca/eng/sct2/sct2_5_e.cfm, accessed 25 January 2008].

COSEWIC (Committee on the Status of Endangered Wildlife in Canada) (2006) Assessment Process and Criteria. COSEWIC, Ottawa, Canada [http://www.cosewic.gc.ca/pdf/assessment_ process_e.pdf, accessed 25 January 2008].

Derocher, A.E., Lunn, N.J. \& Stirling, I. (2004) Polar bears in a warming climate. Integrative and Comparative Biology, 44, 163-176.

Derocher, A.E. \& Stirling, I. (1990) Distribution of polar bears (Ursus maritimus) during the ice-free period in western Hudson Bay. Canadian Journal of Zoology, 68, 1395-1403.

Derocher, A.E. \& Stirling, I. (1992) The population dynamics of polar bears in western Hudson Bay. In Wildlife 2001: Populations (eds D.R. McCullough \& R.H. Barrett), pp. 1150-1159. Elsevier Applied Science, London, UK.

Derocher, A.E. \& Stirling, I. (1995) Temporal variation in reproduction and body mass of polar bears in western Hudson Bay. Canadian Journal of Zoology, 73, 1657-1665.

Derocher, A.E. \& Stirling, I. (1998) Geographic variation in growth of polar bears (Ursus maritimus). Journal of Zoology, 245, $65-72$.

Derocher, A.E., Wiig, Ø. \& Andersen, M. (2002) Diet composition of polar bears in Svalbard and the western Barents Sea. Polar Biology, 25, 448-452.

DFO (Department of Fisheries and Oceans) (2005) Stock Assessment of Northwest Atlantic Harp Seals (Pagophilus groenlandicus). Canadian Science Advisory Secretariat Science Advisory Report 2005/037. Fisheries and Oceans Canada, Ottawa, Canada [http:// www.dfo-mpo.gc.ca/csas/Csas/status/2005/SAR-AS2005_037_E.pdf, accessed 25 January 2008].

Dunbar, M.J. (1951) Eastern Arctic waters. Fisheries Research Board of Canada Bulletin, 88, 1-131.

Ferguson, S.H., Taylor, M.K., Born, E.W. \& Messier, F. (1998) Fractals, sea-ice landscape and spatial patterns of polar bears. Journal of Biogeography, 25, 1081-1092.

Ferguson, S.H., TAylor, M.K., Born, E.W., Rosing-Asvid, A. \& Messier, F. (2001) Activity and movement patterns of polar bears inhabiting consolidated versus active pack ice. Arctic, 54, 49-54.

Fischiach, A.S., Amstrup, S.C. \& Douglas, D.C. (2007) Landward and eastward shift of Alaskan polar bear denning associated with recent sea ice changes. Polar Biology, 30, 1395-1405.

Freeman, M.M.R. \& Wenzel, G.W. (2006) The nature and significance of polar bear conservation hunting in the Canadian Arctic. Arctic, 59, 21-30.

Grainger, E.H. (1975) A marine ecology study in Frobisher Bay, Arctic Canada. In Energy Flow: Its Biological Dimensions. A Summary of IBP in Canada, 1964-1974 (eds T.W.M. Cameron \&
L.W. Billingsly), pp. 262-266. Royal Society of Canada, Ottawa, Canada.

Green, D.M. (2005) Designatable units for status assessment of endangered species. Conservation Biology, 19, 1813-1820.

Hammill, M.O. \& S Sith, T.G. (1989) Factors affecting the distribution and abundance of ringed seal structures in Barrow Strait, Northwest Territories. Canadian Journal of Zoology, 67, 2212-2219.

Hunter, C.M., Caswell, H., Runge, M.C., Regehr, E.V., Amstrup, S.C. \& Stirling, I. (2007) Polar Bears in the Southern Beaufort Sea II: Demography and Population Growth in Relation to Sea Ice Conditions. US Geological Survey Administrative Report, Reston, USA [http://www.usgs.gov/newsroom/special/ polar_bears/docs/USGS_PolarBear_Hunter_SB-I_Demography. pdf, accessed 25 January 2008].

IUCN (2007) 2007 IUCN Red List of Threatened Species. IUCN, Gland, Switzerland. Http://www.iucnredlist.org [accessed 28 September 2007].

IUCN/SSC Polar Bear Specialist Group (2002) Status of the polar bear. In Polar Bears: Proceedings of the 13th Working Meeting of the IUCN/SSC Polar Bear Specialist Group (eds N.J. Lunn, S. Schliebe \& E.W. Born), pp. 21-35. IUCN, Gland, Switzerland.

IUCN/SSC Polar Bear Specialist Group (2006) Status of the polar bear. In Polar Bears: Proceedings of the 14th Working Meeting of the IUCN/SSC Polar Bear Specialist Group (eds J. Aars, N.J. Lunn \& A.E. Derocher), pp. 33-55. IUCN, Gland, Switzerland.

Iverson, S.J., Field, C., Bowen, W.D. \& Blanchard, W. (2004) Quantitative fatty acid signature analysis: a new method of estimating predator diets. Ecological Monographs, 74, 211-235.

Iverson, S.J., Stirling, I. \& Lang, S.L.C. (2006) Spatial and temporal variation in the diets of polar bears across the Canadian Arctic: indicators of changes in prey populations and environment. In Top Predators in Marine Ecosystems (eds I.L. Boyd, S. Wanless \& C.J. Camphuysen), pp. 98-117. Cambridge University Press, New York, USA.

Johnston, D.W., Friedlaender, A.S., Torres, L.G. \& Lavigne, D.M. (2005) Variation in sea ice cover on the east coast of Canada from 1969 to 2002: climate variability and implications for harp and hooded seals. Climate Research, 29, 209-222.

Jonkel, C. (1969) Polar Bear Research in Canada. Canadian Wildlife Service Progress Note No. 13, Ottawa, Canada.

Kingsley, M.C.S., Stirling, I. \& Calvert, W. (1985) The distribution and abundance of seals in the Canadian High Arctic, 1980-82. Canadian Journal of Fisheries and Aquatic Sciences, 42, $1189-1210$.

Lentfer, J.W. (1975) Polar bear denning on drifting sea ice. Journal of Mammalogy, 56, 716-718.

Lentfer, J.W. (1983) Alaskan polar bear movements from mark and recovery. Arctic, 36, 282-288.

Mauritzen, M., Derocher, A.E. \& Wiig, Ø. (2001) Space-use strategies of female polar bears in a dynamic sea ice habitat. Canadian Journal of Zoology, 79, 1704-1713.

MCLaren, I.A. (1958) The biology of the ringed seal (Phoca hispida Schreber) in the eastern Canadian Arctic. Bulletin of the Fisheries Research Board of Canada, 118.

Meehl, G.A., Stocker, T.F., Collins, W.D., Friedlingstein, P., Gaye, A.T., Gregory, J.M. et al. (2007) Global Climate Projections. In Climate Change 2007: The Physical Science Basis. Contribution of Working Group I to the Fourth Assessment Report of the Intergovernmental Panel on Climate Change (eds S. Solomon, D. Qin, M. Manning, Z. Chen, M. Marquis, K.B. Averyt et al.), pp. 747-845. Cambridge University Press, New York, USA. 
Messier, F., Taylor, M.K. \& Ramsay, M.A. (1994) Denning ecology of polar bears in the Canadian Arctic archipelago. Journal of Mammalogy, 75, 420-430.

Molnár, P.K., Derocher, A.E., Lewis, M.A. \& Taylor, M.K. (2008) Modelling the mating system of polar bears: a mechanistic approach to the Allee effect. Proceedings of the Royal Society B, $275,217-226$.

Moore, G.W.K. (2006) Reduction in seasonal sea ice concentration surrounding southern Baffin Island 1979-2004. Geophysical Research Letters, 33, L20501.

Obbard, M.E., Cattet, M.R.L., Moody, T., Walton, L.R., Potter, D., Inglis, J. \& Chenier, C. (2006) Temporal trends in the body condition of southern Hudson Bay polar bears. Climate Change Research Information Note, 3, 1-8. Http://assets.panda.org/ downloads/obbard_et_al_ccrn_3.pdf [accessed 25 January 2008].

Obbard, M.E., McDonald, T.L., Howe, E.J., Regehr, E.V. \& Richardson, E.S. (2007) Polar Bear Population Status in Southern Hudson Bay, Canada. US Geological Survey Administrative Report, Reston, USA [http://www.usgs.gov/newsroom/ special/polar_bears/docs/USGS_PolarBear_Obbard_SHudsonBay. pdf, accessed 25 January 2008].

Paetkau, D., Amstrup, S.C., Born, E.W., Calvert, W., Derocher, A.E., Garner, G.W. et al. (1999) Genetic structure of the world's polar bear populations. Molecular Ecology, 8, 1571-1584.

Parks, E.K., Derocher, A.E. \& Lunn, N.J. (2006) Seasonal and annual movement patterns of polar bears on the sea ice of Hudson Bay. Canadian Journal of Zoology, 84, 1281-1294.

Pomeroy, L.R. (1997) Primary production in the Arctic Ocean estimated from dissolved oxygen. Journal of Marine Systems, 10, $1-8$.

Powles, H., Vendette, V., Siron, R. \& O’Boyle, B. (2004) Proceedings of the Canadian Marine Ecoregions Workshop. DFO Canadian Science Advisory Secretariat Proceedings Series 2004/ o16, Fisheries and Oceans Canada, Ottawa, Canada [http://www dfo-mpo.gc.ca/csas/Csas/Proceedings/2004/PRO2004_016_B.pdf, accessed 25 January 2008].

Prestrud, P. \& Stirling, I. (1994) The International Polar Bear Agreement and the current status of polar bear conservation. Aquatic Mammals, 20, 113-124.

RAmSAY, M.A. \& STIRLING, I. (1988) Reproductive biology and ecology of female polar bears (Ursus maritimus). Journal of Zoology, 214, 601-634.

Regehr, E.V., Amstrup, S.C. \& Stirling, I. (2006) Polar Bear Population Status in the Southern Beaufort Sea. US Geological Survey Open-File Report 2006-1337, Reston, USA.

Regehr, E.V., Hunter, C.M., Caswell, H., Amstrup, S.C. \& Stirling, I. (2007a) Polar Bears in the Southern Beaufort Sea I: Survival and Breeding in Relation to Sea Ice Conditions, 2001-2006. US Geological Survey Administrative Report, Reston, USA [http:// www.usgs.gov/newsroom/special/polar_bears/docs/USGS PolarBear_Regehr_SB-II_Estimation.pdf, accessed 25 January 2008].

Regehr, E.V., Lunn, N.J., Amstrup, S.C. \& Stirling, I. (2007b) Effects of earlier sea ice breakup on survival and population size of polar bears in western Hudson Bay. Journal of Wildlife Management, 71, 2673-2683.

SChweinsburg, R.E. \& LeE, L.J. (1982) Movement of four satellitemonitored polar bears in Lancaster Sound, Northwest Territories. Arctic, 35, 504-511.

Schweinsburg, R.E., Lee, L.J. \& Latour, P.B. (1982) Distribution, movement and abundance of polar bears in Lancaster Sound, Northwest Territories. Arctic, 35, 159-169.

Schweinsburg, R.E., Spencer, W. \& Williams, D. (1984) Polar bear denning area at Gateshead Island, Northwest Territories. Arctic, 37, 169-171.
Smith, T.G. \& S TIRLING, I. (1975) The breeding habitat of the ringed seal (Phoca hispida). The birth lair and associated structures. Canadian Journal of Zoology, 53, 1297-1305.

Spalding, M.D., Fox, H.E., Allen, G.R., Davidson, N., FerdańA, Z.A., Finlayson, M. et al. (2007) Marine ecoregions of the world: a bioregionalization of coastal and shelf areas. BioScience, 57, 573-583.

STIRLING, I. (1980) The biological importance of polynyas in the Canadian Arctic. Arctic, 33, 303-315.

STIRLING, I. (1997) The importance of polynyas, ice edges, and leads to marine mammals and birds. Journal of Marine Systems, 10, 9-21.

Stirling, I. (2002) Polar bears and seals in the eastern Beaufort Sea and Amundsen Gulf: a synthesis of population trends and ecological relationships over three decades. Arctic, 55, Supp. 1, $59-76$.

Stirling, I., Andriashek, D. \& Calvert, W. (1993) Habitat preferences of polar bears in the western Canadian Arctic in late winter and spring. Polar Record, 29, 13-24.

Stirling, I., Calvert, W. \& Andriashek, D. (1980) Population Ecology Studies of the Polar Bear in the Area of South-eastern Baffin Island. Canadian Wildlife Service Occasional Paper No. 44, Ottawa, Canada.

Stirling, I., Calvert, W. \& Andriashek, D. (1984) Polar bear (Ursus maritimus) ecology and environmental considerations in the Canadian High Arctic. In Northern Ecology and Resource Management (eds R. Olson, R. Hastings \& F. Geddes), pp. 201-222. University of Alberta Press, Edmonton, Canada.

Stirling, I., Jonkel, C., Smith, P., Robertson, R. \& Cross, D. (1977) The Ecology of the Polar Bear (Ursus maritimus) along the Western Coast of Hudson Bay. Canadian Wildlife Service Occasional Paper No. 33, Ottawa, Canada.

Stirling, I. \& Kilia an, H.P.L. (1980) Population Ecology Studies of the Polar Bear in Northern Labrador. Canadian Wildlife Service Occasional Paper No. 42, Ottawa, Canada.

Stirling, I., LunN, N.J. \& I acozza, J. (1999) Long-term trends in the population ecology of polar bears in western Hudson Bay in relation to climatic change. Arctic, 52, 294-306.

Stirling, I., Lunn, N.J., Iacozza, J., Elliott, C. \& Obbard, M. (2004) Polar bear distribution and abundance on the southwestern Hudson Bay coast during open water season, in relation to population trends and annual ice patterns. Arctic, 57, 15-26.

Stirling, I., McDonald, T.L., Richardson, E.S. \& Regehr, E.V. (2007) Polar Bear Population Status in the Northern Beaufort Sea. US Geological Survey Administrative Report, Reston, USA [http:// www.usgs.gov/newsroom/special/polar_bears/docs/USGS_ PolarBear_Stirling_NBeaufortSea.pdf, accessed 25 January 2008].

Stirling, I. \& Øritsland, N.A. (1995) Relationships between estimates of ringed seal (Phoca hispida) and polar bear (Ursus maritimus) populations in the Canadian Arctic. Canadian Journal of Fisheries and Aquatic Sciences, 52, 2594-2612.

Stirling, I. \& Parkinson, C.L. (2006) Possible effects of climate warming on selected populations of polar bears (Ursus maritimus) in the Canadian Arctic. Arctic, 59, 261-275.

Stirling, I., Pearson, A.M. \& Bunnell, F.L. (1976) Population ecology studies of polar and grizzly bears in Northern Canada. Transactions of the North American Wildlife and Natural Resources Conference, 41, 421-430.

Stirling, I., Richardson, E., Thiemann, G.W. \& Derocher, A.E. (2008) Unusual predation attempts of polar bears on ringed seals in the southern Beaufort Sea: possible significance of changing spring ice conditions. Arctic, 61, 14-22.

Stirling, I. \& T A Ylor, M.K. (1999) Update COSEWIC Status Report on Polar Bear (Ursus maritimus). COSEWIC, Ottawa, Canada. 
Stroeve, J., Holland, M.M., Meier, W., Scambos, T. \& Serreze, M. (2007) Arctic sea ice decline: faster than forecast. Geophysical Research Letters, 34, L09501.

Subba Rao, D.V. \& Platt, T. (1984) Primary production of Arctic waters. Polar Biology, 3, 191-201.

TAylor, M. \& Lee, J. (1995) Distribution and abundance of Canadian polar bear populations: a management perspective. Arctic, 48, 147-154.

Taylor, M.K., Akeeagok, S., Andriashek, D., Barbour, W., Born, E.W., Calvert, W. et al. (2001) Delineating Canadian and Greenland polar bear (Ursus maritimus) populations by cluster analysis of movements. Canadian Journal of Zoology, 79, 690-709.

Taylor, M.K., Laake, J., Mcloughlin, P.D., Cluff, H.D. \& Messier, F. (2006) Demographic parameters and harvest-explicit population viability analysis for polar bears in M'Clintock Channel, Nunavut, Canada. Journal of Wildlife Management, 70, $1667-1673$.

Thiemann, G.W. (2006) Continental scale variation in polar bear (Ursus maritimus) diets and the fatty acid signatures of their marine mammal prey. $\mathrm{PhD}$ thesis, Dalhousie University, Halifax, Canada.

Thiemann, G.W., Iverson, S.J. \& S Tirling, I. (in press) Polar bear diets composition and Arctic marine food webs: insights from fatty acid analysis. Ecological Monographs.

USFWS (US Fish and Wildlife Service) (2008) Endangered and threatened wildlife and plants; determination of threatened status for the polar bear (Ursus maritimus) throughout its range; final rule. Federal Register, 73, 28211-28303.
Van de Velde, F., Stirling, I. \& Richardson, E. (2003) Polar bear (Ursus maritimus) denning in the area of the Simpson Peninsula, Nunavut. Arctic, 56, 191-197.

Welch, H.E., Bergmann, M.A., Siferd, T.D., Martin, K.A., Curtis, M.F., Craw Ford, R.E. et al. (1992) Energy flow through the marine ecosystem of the Lancaster Sound region, Arctic Canada. Arctic, 45, 343-357.

Wilson, D.E. (1976) Cranial variation in polar bears. In Bears Their Biology and Management (eds M.R. Pelton, J.W. Lentfer \& G.E. Folk), pp. 447-453. IUCN, Morges, Switzerland.

\section{Biographical sketches}

Gregory Thiemann's research focuses on the foraging ecology of Arctic predators. He has studied the impact of environmental conditions on food web interactions in terrestrial, marine, and freshwater ecosystems. He is also a member of the IUCN/SSC Polar Bear Specialist Group. ANdREW Derocher specializes in the ecology, conservation and management of large Arctic mammals. $\mathrm{He}$ has examined the limiting and regulating factors influencing polar bear populations for more than 20 years and is the current Chair of the IUCN/SSC Polar Bear Specialist Group. IAN STIRLING has studied polar ecosystems, marine mammals and polar bears for more than 40 years. His research examines the behaviour, ecology, evolution, and conservation of marine mammals. He has been a member of the IUCN/SSC Polar Bear Specialist Group since 1974. 